\title{
Monosodium Glutamate Alters the Function and Morphology of the Parotid Gland in Sprague Dawley Rats
}

\author{
Glutamato Monosódico Altera la Función y Morfología \\ de la Glándula Parótida en Ratas Sprague Dawley
}

Ignacio $\operatorname{Roa}^{1} \&$ Mariano del Sol ${ }^{2,3}$

ROA, I. \& DEL SOL, M. Monosodium glutamate alters the function and morphology of the parotid gland in sprague dawley rats. Int. J. Morphol., 38(4):1112-1119, 2020.

SUMMARY: Monosodium glutamate (MSG) is a flavor enhancer widely used in the food industry, with obesogenic properties, in addition to causing alterations in the oral cavity. The aim of the study was to observe the morphofunctional changes in the parotid gland after the administration of MSG in rats. 18 newborn male Sprague Dawley rats were used, divided into three groups (Control group; MSG1 group: $4 \mathrm{mg} / \mathrm{g}$ weight of monosodium glutamate, 5 doses, kept for 8 weeks, and MSG2 group: 4 mg/g weight of MSG, 5 doses, kept for 16 weeks). The body mass index (BMI) was calculated, and the salivary flow, $\mathrm{pH}$, a-amylase activity, $\mathrm{Na}, \mathrm{Cl}, \mathrm{K}$ and $\mathrm{Ca}$ were analyzed by quantitative analysis. After euthanasia by ketamine/xylazine overdose, parotid volume was analyzed and stereology was performed. MSG administration caused an increase in BMI and a decrease in parotid volume as well as a reduction in salivary flow and $\mathrm{pH}$ and an increase in a-amylase activity, also increasing the salivary sodium and chlorine levels. Alterations in the normal stereological parameters of the gland were observed. Exposure to MSG caused morphofunctional alterations at parotid gland.

KEY WORDS: Monosodium glutamate; Saliva; Parotid gland; Salivary flow; $p H$; $\alpha$-amylase.

\section{INTRODUCTION}

The obesogenic properties of monosodium glutamate (MSG) have been studied by various authors (Bunyan et al., 1976; Baculikova et al., 2008; Miranda et al., 2017), observing that its ingestion may be associated with the increased risk of overweight regardless of physical activity and total energy consumption in humans (He et al., 2008; Beregova et al., 2014). It is also associated with insulin resistance (Hirata et al., 1997) and hyperinsulinemia (Marmo et al., 1994) in obesity models in rats, as well as increased adiposity and obesity (Dolnikoff et al., 2001).

At the systemic level, the harmful effect of MSG has been reported in several structures, such as the central nervous system, fatty tissue, liver, digestive tract and reproductive organs, among others (Collison et al., 2010a; Husarova \& Ostatnikova, 2013, López-Miranda et al., 2015) On the other hand, obesity has been linked to various alterations in the oral cavity, such as caries, periodontitis and xerostomia (Barreto Villela et al., 2004; Saito et al., 2005, Mathus-Vliegen et al., 2007; Flink et al., 2008; Ueda et al., 2013, Salamonowicz et al., 2019).
The existing literature on the relation between obesity and salivary glands is still scarce, concentrating mainly on its effects on the functional activity of the glands (Inoue $e t$ al., 1977; Renzi et al., 1989; Mozaffari et al., 2011; Zalewska et al., 2014), with the likely structural changes at glandular level still being poorly documented. The aim of the study was to observe the morphofunctional changes in the parotid gland after the administration of MSG in rats.

\section{MATERIAL AND METHOD}

Animals and Experimental Protocol. Eighteen newborn male Sprague Dawley rats were used (2 days old). At the beginning of the experimental period (day 1), the rats were divided into three groups: Control group $(n=6)$ : exposed to saline solution (sodium chloride $0.9 \%(\mathrm{p} / \mathrm{v})$ in distilled water) $8 \mathrm{ml} / \mathrm{g}$ administered subcutaneously. MSG1 group: $(\mathrm{n}=6)$ exposed to subcutaneous MSG, $4 \mathrm{mg} / \mathrm{g}$ weight two doses, $2^{\text {nd }}$ and $4^{\text {th }}$ day and $2 \mathrm{mg} / \mathrm{g}$ weight, $6^{\text {th }}, 8^{\text {th }}, 10^{\text {th }}$ day

\footnotetext{
${ }^{1}$ Unidad de Morfología, Departamento de Ciencias Básicas Biomédicas, Facultad de Ciencias de la Salud, Universidad de Talca, Talca, Chile.

${ }^{2}$ Centro de Excelencia en Ciencias Morfológicas y Quirúrgicas (CEMyQ), Universidad de La Frontera, Temuco, Chile.

${ }^{3}$ Programa Doctorado en Ciencias Morfológicas, Facultad de Medicina, Universidad de La Frontera. Temuco, Chile.
} 
(Mathus-Vliegen et al.), kept for 8 weeks. MSG2 group: $(\mathrm{n}=6)$ exposed to subcutaneous MSG, $4 \mathrm{mg} / \mathrm{g}$ weight two doses, 2nd and 4th day and $2 \mathrm{mg} / \mathrm{g}$ weight, 6th, 8th, 10th day (Mathus-Vliegen et al.), kept for 16 weeks.

The rats were housed in individual cages for 16 weeks in the vivarium of the Center for Excellence in Morphological and Surgical Studies (CEMyQ) at the Universidad de La Frontera, Temuco, Chile, kept at $22 \pm 2{ }^{\circ} \mathrm{C}$ and $50 \%-70 \%$ humidity and a $12 \mathrm{~h}$ light/dark cycle (8:00 a.m. $-8: 00$ p.m. $/ 8: 00$ p.m. $-8: 00$ a.m.). A standard laboratory diet (AIN-93M) and water ad libitum were administered. The study was approved by the Scientific Ethics Committee of the Universidad de La Frontera, Temuco, Chile ( ${ }^{\circ} 051 /$ 2017).

Nutritional status and parotid gland volume. The nutritional status of the rats was obtained by calculating the body mass index (BMI) [the relation of the rats' body weight (g) and the square of the body length $\left.\left(\mathrm{cm}^{2}\right)\right]$ (Contini et al., 2012). The parotid gland volume was measured using Scherle's method (1970).

Salivary analysis. The saliva was collected from the oral cavity under parasympathetic stimulation to increase the flow and facilitate saliva collection. The animals were given $2 \%$ pilocarpine hydrochloride $(2 \mathrm{mg} / \mathrm{kg}$ of body weight s.c.), then the saliva was aspirated using a micropipette, storing it in an Eppendorf tube kept on ice, to which $60 \mathrm{~mL}$ of a protease inhibitor had been previously added (Protease Inhibitor Cocktail set I, Merck, Darmstadt, Germany) to minimize protein loss. The salivary $\mathrm{pH}$ was obtained using $\mathrm{pH}$ indicator strips (MQuant ${ }^{\circ}$, Merck, Darmstadt, Germany). The salivary flow was determined with a $20-200 \mathrm{~mL}$ micropipette (BioPetteTM, NJ, USA) for $10 \mathrm{~min}$. The salivary amylase was determined in $10 \mathrm{ml}$ of sample in $1 \mathrm{ml}$ of colorimetric reagent (a-amylase liquicolor, Human, Wiesbaden, Germany) at $37^{\circ} \mathrm{C}$ in a multimodal reader (Synergy TM H1, Biotek, USA).

Salivary elementary semiquantitative microanalysis. For the determination of the salivary elements, an EDX elementary semiquantitative microanalysis was performed in a scanning electron micrograph (VP-SEM) (SU 3500 Hitachi, Japan) coupled to an EDX detector (Quantax, Bruker, Berlin, Germany). $50 \mathrm{ml}$ of saliva were deposited on double-sided carbon tape mounted to the stub, and dried at $30{ }^{\circ} \mathrm{C}$ for $10 \mathrm{~min}$ (carbon control tape). An elementary semiquantitative microanalysis was conducted on the samples under the following parameters: energy $15 \mathrm{KV}$, working distance (WD) $10 \mathrm{~mm}$ approx., BSD-3D detector, magnification 500X, pressure $6 \mathrm{~Pa}$.
Parotid gland stereological analysis. Once the parotid glands had been obtained, they were fixed in buffered formalin $(1.27 \mathrm{~mol} / \mathrm{l}$ of formaldehyde in phosphate buffer $0.1 \mathrm{M} \mathrm{pH}$ 7.2) for $48 \mathrm{~h}$, dehydrated and embedded in Paraplast Plus (Sigma-Aldrich Co., St. Louis, MO, U.S.A.). Once the blocks were obtained, 5 sections were made, 5 mm thick (Leica ${ }^{\circledR}$ RM2255), and stained with H\&E.

Five fields were observed for each section; in total 125 fields per group. The slides were observed under an optical microscope (Leica ${ }^{\circledR}$, DM750, Switzerland) with integrated camera (Leica ${ }^{\circledR}$ ICC50W, Nussloch, Germany) and the images were projected onto a flat screen monitor (View Sonic $®)$. The analyzed parameters were: adenomere volume density $\left(\mathrm{V}_{\text {vad }}\right)$, adenomere surface density $\left(\mathrm{S}_{\mathrm{vad}}\right)$ and adenomere area density $\left(\mathrm{NA}_{\mathrm{ad}}\right)$ measured using the multipurpose test system M42 (Mandarim-de-Lacerda \& del Sol, 2017). This same sequence was applied to the system of total and striated ducts $\left(\mathrm{V}_{\mathrm{vtc}}, \mathrm{S}_{\mathrm{vtc}}, \mathrm{NA}_{\mathrm{tc}}, \mathrm{V}_{\mathrm{vstr}}, \mathrm{S}_{\mathrm{vstr}}, \mathrm{NA}_{\text {strt }}\right.$, respectively). For the parameter cell number density of the adenomere (Nvac), an optical microscope (Leica ${ }^{\circledR}$ DM2000 LED, Wetzlar, Germany) was used with a Z-axis motorized stage (Prior®, Rockland, MA., USA) and a HD digital camera (Leica ${ }^{\circledR}$ MC170 HD, Heerbrugg, Switzerland), where a nucleus was considered representative of a cell.

Statistical analysis. The data were analyzed in the program Microsoft ${ }^{\circledR}$ Excel Mac (version 2011, CA, USA) and GraphPad Prism ${ }^{\circledR}$ (version 5.0 San Diego, USA). For the distribution of the data the Kolmogorov-Smirnov test (analysis of data normality) or Shapiro-Wilk test was used. Depending on the normality of the data distribution, a oneway ANOVA or Kruskal-Wallis test was used, followed by Tukey's post hoc test. A level of $\mathrm{p}<0.05$ was considered significant.

\section{RESULTS}

MSG caused increased BMI and reduced parotid volume. Upon completion of the experimental period, an increase in the rats' BMI was observed in both the MSG1 and MSG2 groups compared to the control group, results which were not statistically significant. With respect to the parotid volume, it presented a decrease in the MSG1 group $(0.16 \pm 0.9$ $\left.\mathrm{cm}^{3}\right)$ and MSG2 group $\left(0.27 \pm 0.06 \mathrm{~cm}^{3}\right)$ compared to the control group $\left(0.52 \pm 0.19 \mathrm{~cm}^{3}\right)$, which was statistically significant $(\mathrm{p}=0.0014)$.

MSG caused a decrease in $\mathrm{pH}$ levels, salivary flow and an increase in a-amylase, as well as changes in the percentages of salivary elements. 
After the experimental period, the rats in the MSG1 and MSG2 groups showed a reduction in salivary $\mathrm{pH}, \mathrm{MSG} 1$ (8.4 \pm 0.48$),$ MSG2 (7.7 \pm 0.23$)$ and control $(8.8 \pm 0.36)$, a statistically significant result $(\mathrm{p}=0.0009)$ for MSG2. The salivary flow rates by group were: control $(33.5 \pm 9.29 \mathrm{~mL} /$ $\mathrm{min})$, MSG1 (20.3 $\pm 1.3 \mathrm{~mL} / \mathrm{min})$ and MSG2 (19.3 $\pm 6.4 \mathrm{~mL} /$ min), with a decrease in the MSG1 and MSG2 groups being noted - statistically significant results $(\mathrm{p}=0.003)$. The aamylase presented increases in the MSG1 (16579 $\pm 7223 \mathrm{U} /$ L) and MSG2 groups (11732 \pm 3999 U/L) compared to the control group (5905 $\pm 1668 \mathrm{U} / \mathrm{L})$, significant only for the control group /MSG1 ( $\mathrm{p}=0.0073)$.
The values for the elements determined in the saliva appear in Table I. Exposure to MSG induced changes in salivary electrolytes, there being statistically significant differences in the increases in sodium in both the MSG1 (5.47 \pm 2.44$)$ and MSG2 (5.18 \pm 1.79$)$ groups compared to the control (3.78 \pm 1.89$)(\mathrm{p}=0.0002)$. In the same way, the chloride presented statistically significant increases $(\mathrm{p}=<0.0001)$ in both the MSG1 and MSG2 groups compared to the control group. The potassium and calcium showed slight reductions in the MSG1 and MSG2 groups compared to the control group, results that were not statistically significant ( $\mathrm{p}=$ 0.0890 and 0.2805 respectively).

Table I. Salivary elementary semiquantitative microanalysis of male Sprague Dawley rat subjected to MSG.

\begin{tabular}{ccccc}
\hline Mass percent (\%) & Groups & MSG2 & $\boldsymbol{p}$ \\
& Control & MSG1 & $5.18 \pm 1.79 \mathrm{~b}$ & 0.0002 \\
$\mathrm{Na}$ & $3.78 \pm 1.89$ & $5.47 \pm 2.44^{\mathrm{a}}$ & $19.85 \pm 6.98 \mathrm{~d}$ & $<0.0001$ \\
$\mathrm{Cl}$ & $14.17 \pm 4.78$ & $17.44 \pm 5.8^{\mathrm{c}}$ & $12.20 \pm 4.33$ & 0.0890 \\
$\mathrm{~K}$ & $13.3 \pm 5.08$ & $10.96 \pm 4.67$ & $1.45 .2 \pm 0.78$ & 0.2805 \\
$\mathrm{Ca}$ & $3.25 \pm 3.64$ & $1.77 \pm 1.93$ & & \\
\hline
\end{tabular}

a: Dif. sig. control/MSG1 ( $\mathrm{p}=0.005)$, según análisis de ANOVA.

b: Dif. sig. control/MSG2 ( $\mathrm{p}=0.005)$, según análisis de ANOVA.

c: Dif. sig. control/MSG2 ( $\mathrm{p}=0.05)$, según análisis de ANOVA.

d: Dif. sig. control/MSG2 ( $<<0.0001)$, según análisis de ANOVA.
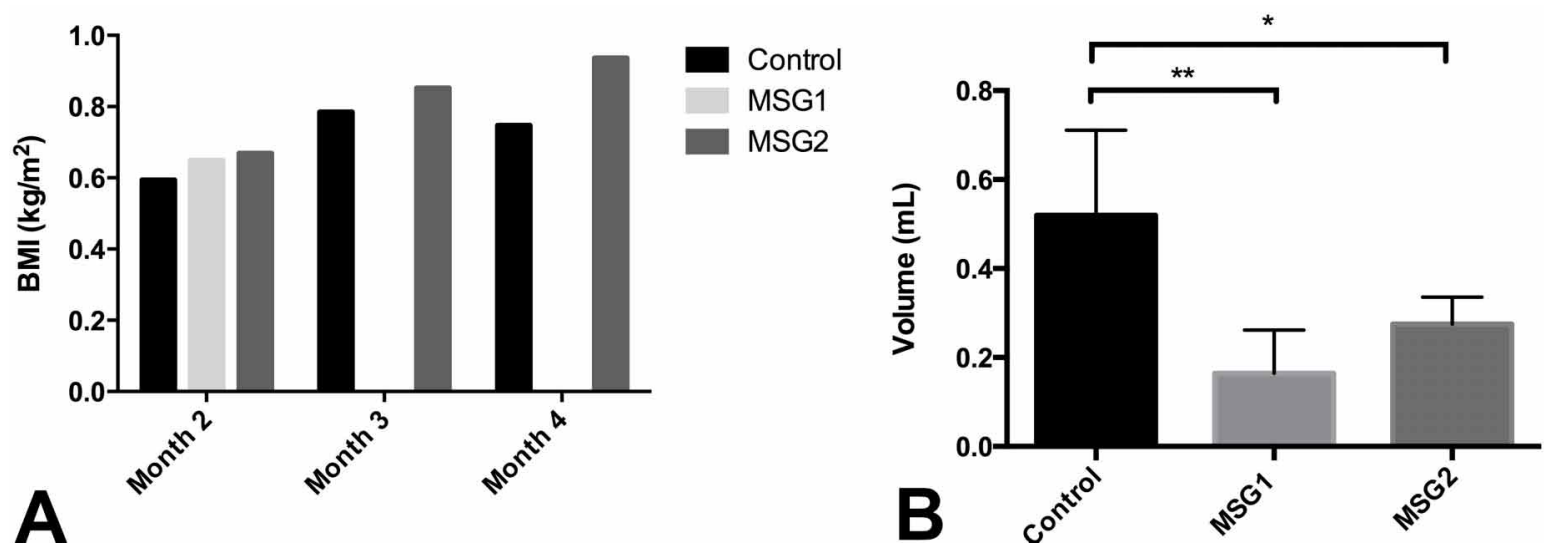

Fig.1. Effects of MSG on BMI and parotid volume in rats exposed for 8 and 16 weeks and control group. A: MSG increases the BMI, time-dependent. B: MSG reduces parotid volume.
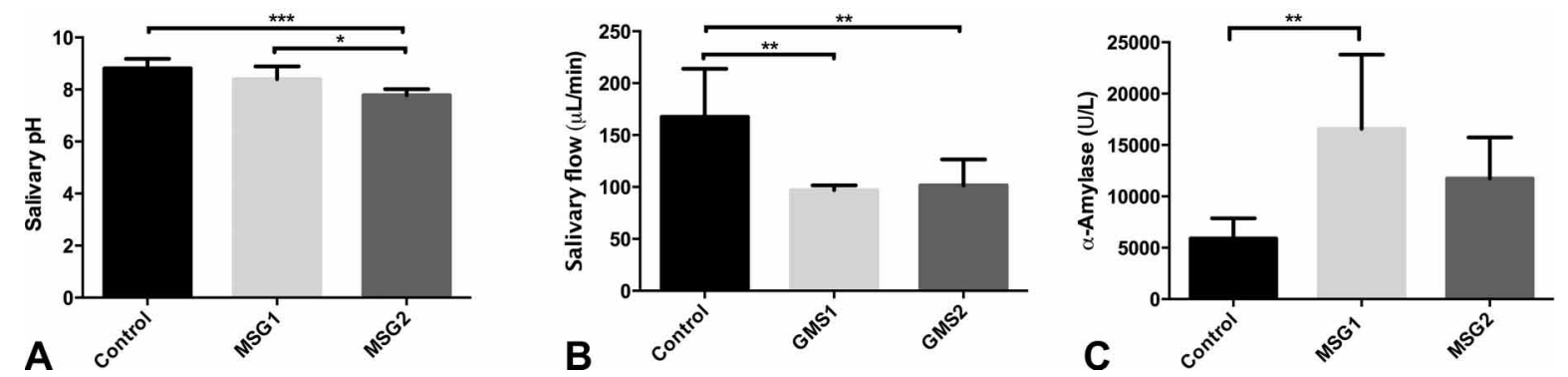

Fig.2. Effects of MSG on pH, salivary flow and a-amylase activity in rats exposed for 8 and 16 weeks and control group. A: MSG reduces salivary $\mathrm{pH}$. B: MSG reduces salivary flow. C: MSG increases a-amylase activity. 
MSG caused changes in the stereological parameters. The stereological analysis reflected a reduction in adenomere $\mathrm{Vv}$, $\mathrm{Sv}$ and NA of the parotid gland in the MSG1 and MSG2 groups, statistically significant values $(\mathrm{p}<0.001,<0.001$ and 0.0099 respectively) compared to the control group. On the other hand, the Vv and Sv of the striated ducts of the parotid gland in the MSG1 and MSG2 groups decreased in comparison with the control group ( $\mathrm{p}<0.001)$. The total ducts showed a decrease in $\mathrm{Vv}, \mathrm{NA}$ and $\mathrm{Sv}$, with the last one presenting statistically significant differences $(p<0.001)$. The parameter of the $\mathrm{Nv}$ of adenomere cells showed a reduction for both the MSG1 and MSG2 groups compared to the control group, a statistically significant result for MSG2 ( $\mathrm{p}=$ 0.0024).
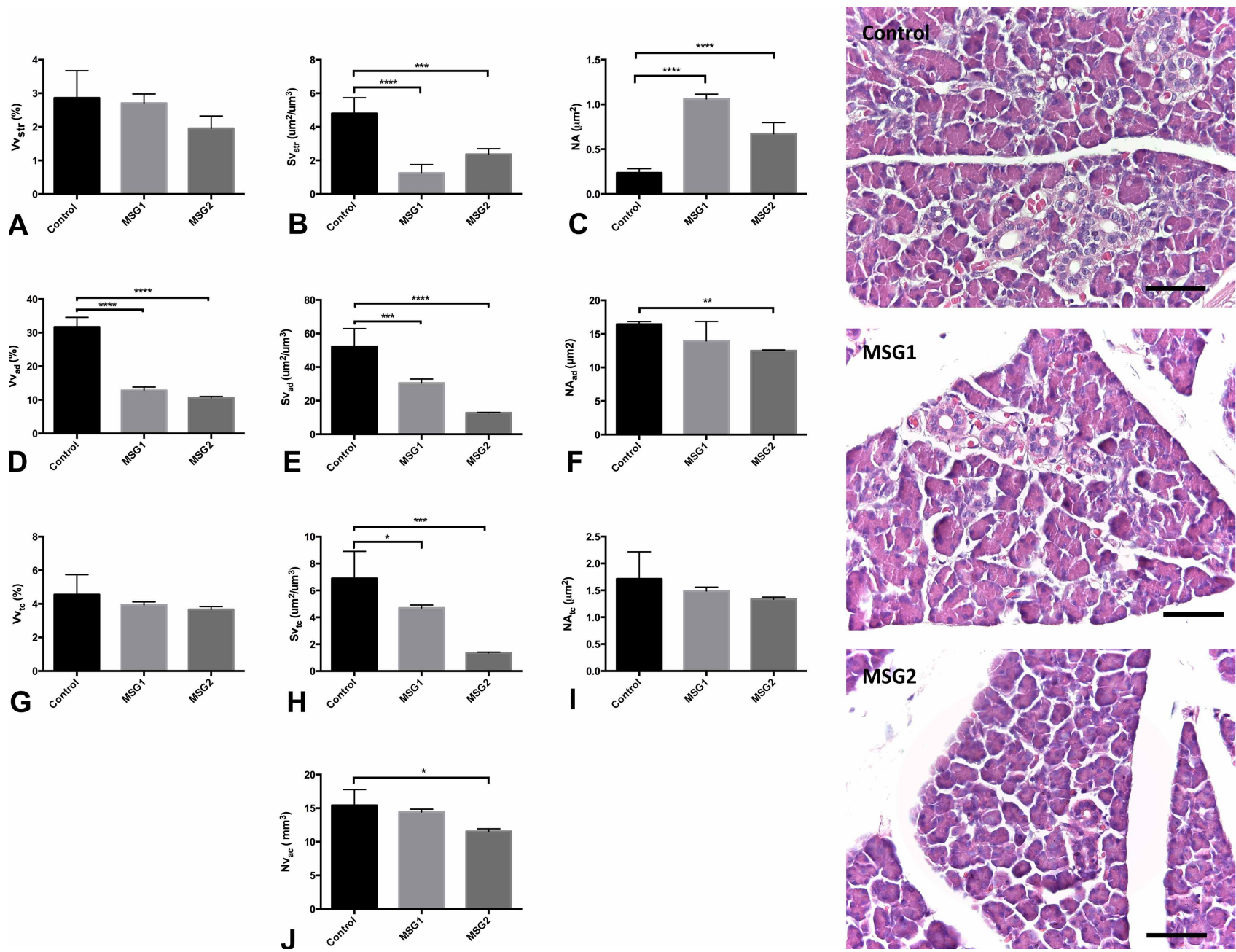

Fig.3. A-J: Effects of MSG on stereological parameters in rats exposed for 8 and 16 weeks and control group. Parotid aspects of Control, and experimental groups (H/E). $50 \mu \mathrm{m}$ barr.

\section{DISCUSSION}

MSG is the sodium salt of glutamate, an amino acid found naturally in multiple foods (Jinap \& Hajeb, 2010; Behrens et al., 2011) and which is currently a widely consumed food additive (Shi et al.). According to Von Diemen et al. (2006), the administration of MSG in newborn rats causes the destruction of the hypothalamic ventromedial and arcuate nuclei, with these animals later developing obesity due to the lack of control between absorption and energy expenditure. In addition, changes to the central nervous system, fatty tissue, liver and reproductive organs have been reported (Husarova \& Ostatnikova), as well as in the oral structures (Beregova et al.; Hordiienko et al., 2014).

The administration of MSG in the rats in the experimental groups induced greater weight gain than in the rats in the control group, reflected in an increased BMI; this 
increase is related to the exposure time: the greater the exposure time to MSG, the higher the BMI. Previous studies indicate that MSG consumption produces a significant increase in body weight, both in animal models and in humans (Abd El-Aziz et al., 2014; Collison et al., 2010b; He et al., 2008, 2011; Insawang et al., 2012; Matysková et al., 2008). Iwase et al. (2000) describe obesity and the increase in food ingestion as being related to the increase in leptin resistance in the arcuate nucleus, which is damaged by the action of MSG (Von Diemen et al.).

Although the association of MSG with the increased risk of overweight has been widely reported, the data obtained from studies on humans or experiments on animals is controversial and has not been fully confirmed (Ebert, 2009). Kondoh \& Torii (1995) indicated that MSG suppresses weight increase, fat deposition and leptin levels in Sprague-Dawley rats. Similarly, Shi et al. (2010) reported that MSG ingestion was not associated with a greater prevalence of obesity or with a clinically significant weight increase in Chinese adults.

MSG administration decreased the parotid volume in the experimental groups compared to the animals who did not receive it, a decrease possibly associated with the MSG administration period. An exposure of 8 weeks (MSG1) induced a greater reduction in the parotid volume $(0.16 \pm 0.9$ $\mathrm{cm}^{3}$ ) than in the MSG2 group induced for 16 weeks $\left(0.27 \pm 0.06 \mathrm{~cm}^{3}\right)$, which indicated that the parotid gland could partially recover its volume, although not achieving normality. Although there are no records of a volume/obesity association, there is evidence between the reduction in the weight of the salivary glands in rats and obesity induced by hypothalamic damage (Inoue et al.), induced by neonatal administration of MSG. In addition, pathologies like diabetes induce changes in the weight of the salivary glands; Ibuki et al. (2010) demonstrated a significant reduction in the mass of the submandibular gland in diabetes induced in rats. Other authors have reported atrophy of the parotid and submandibular glands accompanied by a degeneration of the acinus (Takai et al., 1983; Anderson et al., 1990; Anderson et al., 1994).

Change data in the architecture of the parotid gland have scarcely been reported in the literature in obesity models. From the histological point of view, at adenomere level, a reduction in volume density (Vvad), surface density (Svad) and area density (NAad) were noted in both the MSG1 and MSG2 groups, which pointed to a reduction in the volume and surface of the adenomeres, which these occupy within the gland, in addition to a decrease in the acinar cell number density (Nvac). These results are similar to those of Renzi et al., who reported hypotrophy of the adenomeres of the submandibular gland and a reduction in glandular mass after the induction of hyperphagia due to injury of the ventromedial nucleus of the hypothalamus, a lesion similar to that presented due to MSG consumption. By contrast, no changes were noted in the architecture of the submandibular gland in a model of genetically induced obesity (Zucker rats) (Renzi et al.) despite there being proinflammatory changes (Mozaffari et al.).

The total ducts decreased in both volume density and surface density in the groups exposed to MSG, indicating a reduction not only in striated ducts, but also in intercalated and excretory ducts. Although there are insufficient studies that link obesity to changes in the salivary glands, other obesity-related pathologies do show alterations in these glands (Lilliu et al., 2015). Additionally, decreases in the stereological parameters of the striated ducts in both experimental groups were observed, such as volume density (Vvstr) and surface density (Svstr) as a result of the MSG. This reduction is associated with concentration changes in salivary electrolytes in the MSG1 and MSG2 groups, where $\mathrm{Na}+$ and $\mathrm{Cl}$ - were affected, electrolytes absorbed in the striated duct.

With respect to the functional parameters of the parotid gland, the experimental groups presented alterations in the amount and $\mathrm{pH}$ of saliva, as well as in the a-amylase concentration. The amount of saliva observed in the MSG1 and MSG2 groups was less, yielding statistically significant differences. Previously reported results (Modéer et al., 2010; de Campos et al., 2014; Choromanska et al., 2015) related reductions in salivary flow in obesity, associating this reduction with dental caries, thus strengthening even more the negative effect of obesity on oral health (Herrera et al., 1988; Leone \& Oppenheim, 2001; Modéer et al., 2010). For their part, Sassaki et al. (2003) reported similar results in a MSG-induced obesity model. The $\mathrm{pH}$ decreased significantly in the groups exposed to MSG, demonstrating its effect on glandular function, results similar to those reported by Ain et al. (2016) in Indian children, where they noted the existing relation between the decrease in $\mathrm{pH}$ and the increase in $\mathrm{BMI}$ and decrease in salivary flow. The decrease in salivary $\mathrm{pH}$ could be due to the direct relation between salivary flow and amount of bicarbonate, because when there is less salivary flow, less bicarbonate is released, which reduces the $\mathrm{pH}$. Matczuk et al. (2016) described the changes in the $\mathrm{pH}$ of the salivary glands as possibly leading to detrimental changes in their structure, impacting on their functions, and causing hyposalivation, similar to what was observed in our study. On the other hand, Pannunzio et al. (2010) did not observe any changes in the salivary $\mathrm{pH}$ in obese or overweight children compared to those of normal weight, the same result obtained with the parameter salivary flow. 
$\alpha$-amylase is an important component in the secretion of the parotid gland, secreted by the serous cells of the adenomere, with an important enzymatic function (Humphrey \& Williamson, 2001; Rohleder \& Nater, 2009). With respect to the a-amylase values, this enzyme increased in both groups exposed to MSG, thus in the animals in the MSG1 group, exposed to only 8 weeks, there were higher values, which decreased after 16 weeks, not reaching normality. This increase was reported previously by Sassaki et al. and Rodrigues et al. (2015) in obese animals, in MSGinduced obesity models and diets rich in fats, respectively. Although in our results there was a reduction in the number of acinar cells, the a-amylase secretion increased, which could be explained by a compensatory response by these cells. A possible explanation of the increase in active aamylase could be due to the $\mathrm{pH}$ determined in the experimental groups, which are closer to the optimal activation $\mathrm{pH}$ of this enzyme, which are over $\mathrm{pH} 6$ (Pedersen et al., 2018), being affected also in conditions of hypofunction of the salivary gland (Lynge Pedersen \& Belstrøm, 2019).

The glandular activity is intimately related to the morphological changes, explained partly by the proinflammatory effects induced by obesity/overweight in the salivary glands, produced mainly by the action of proinflammatory cytokines derived from adipocytes and macrophages present in the fatty tissue, which might negatively affect the function of the salivary glands (Modéer et al., 2011), in addition to the oxidative changes produced by MSG at glandular level, thus causing the development of oxidative stress (Beregova et al.; Hordiienko et al.).

\section{CONCLUSION}

Exposure to MSG caused morphofunctional alterations at parotid level, with a reduction in the volume of the gland being observed, accompanied by changes in the adenomere and striated ducts in the gland, involved in the production, secretion and modification of saliva, which was altered in flow, $\mathrm{pH}$ and in its components.

ACKNOWLEDGEMENTS. Financial support CONICYT-PCHA/Doctorado Nacional/2015-21150235.

ROA, I. \& DEL SOL, M. Glutamato monosódico altera la función y morfología de la glándula parótida en ratas Sprague Dawley. Int. J. Morphol., 38(4):1112-1119, 2020.

RESUMEN: El glutamato monosódico (MSG), es un potenciador del sabor ampliamente utilizado en la industria alimentaria. Diversos estudios han propuesto la relación entre éste y el desarrollo de obesidad, además de provocar alteraciones en la cavidad oral. El objetivo del estudio fue observar los cambios morfofuncionales a nivel de la glándula parótida, posterior a la administración de MSG en ratas. Se utilizaron 18 ratas neonatas Sprague Dawley machos, divididas en tres grupos según su tiempo de exposición y dosis a MSG (Grupo Control, Grupo MSG1: 4 $\mathrm{mg} / \mathrm{g}$ peso de glutamato monosódico, 5 dosis, mantenidas 8 semanas, Grupo MSG2: $4 \mathrm{mg} / \mathrm{g}$ peso de MSG, 5 dosis, mantenidas 16 semanas. Fue calculado el índice de masa corporal (BMI), además de ser analizado el flujo salival, $\mathrm{pH}$, actividad de $\alpha$-amilasa, y Na, $\mathrm{Cl}, \mathrm{K}$ y Ca mediante análisis semicuantitativo. Luego de la eutanasia por sobredosis de ketamina/xilasina, las glándulas parótidas fueron extraídas y analizado su volumen y fueron procesadas para histología, y estudio estereológico. La administración de MSG causó aumento en BMI y disminución del volumen parotídeo, además de disminución del flujo y pH salival, así como aumento en actividad de la a-amilasa, aumentando además los niveles de sodio y cloro salival. Fueron observadas alteraciones a nivel de los parámetros estereológicos normales de la glándula. La exposición a MSG causó alteraciones morfofuncionales a nivel parotídeo, observándose una disminución del volumen de la glándula, acompañado de alteraciones en el adenómero y conductos estriados de la glándula, implicados en la producción, secreción y modificación de la saliva, la cual se vio alterada, en el flujo, pH, y en sus componentes.

PALABRAS CLAVE: Glutamato monosódico; Saliva; Glándula parótida; Flujo salival; pH; $\alpha$-amilasa.

\section{REFERENCES}

Abd El-Aziz, G. S.; El-Fark, M. O.; Hassan, A. M. \& Badawoud, M. H. Effects of prolonged oral intake of monosodium glutamate (MSG) on body weight and its correlation to stomach histopathological changes in male rats. Thai. J. Vet. Med., 44:201-8, 2014.

Ain, T. S.; Sultan, S.; Gowhar, O.; Ravishankar, T. L. \& Kumar, S. Obesity and salivary parameters (flow rate, buffer capacity, and salivary $\mathrm{pH}$ ) in children of Moradabad, India. Int. J. Sci. Study, 4:25-9, 2016.

Anderson, L. C.; Garret, J. R. \& Proctor, G. B. Morphological effects of sympathetic nerve stimulation on rat parotid glands 3-4 weeks after the induction of streptozotocin diabetes. Arch. Oral Biol., 35:829-38, 1990.

Anderson, L. C.; Suleiman, A. H. \& Garrett, J. R. Morphological effects of diabetes on the granular ducts and acini of the rat submandibular gland. Microsc. Res. Tech., 27:61-70, 1994.

Baculikova, M.; Fiala, R.; Jezova, D.; Macho, L. \& Zorad, S. Rats with monosodium glutamate-induced obesity and insulin resistance exhibit low expression of G alpha (i2) G-protein. Gen. Physiol. Biophys., 27:222-6, 2008.

Barreto Villela, N.; Braghrolli Neto, O.; Lima Curvello, K.; Eduarda Paneili, B.; Seal, C.; Santos, D. \& Cruz, T. Quality of life of obese patients submitted to bariatric surgery. Nutr. Hosp., 19:367-71, 2004.

Behrens, M.; Meyerhof, W.; Hellfritsch, C. \& Hofmann, T. Sweet and umami taste: natural products, their chemosensory targets, and beyond. Angew. Chem. Int. Ed. Engl., 50:2220-42, 2011.

Bereregova, T. V.; Falalyeyeva, T. M.; Neporada, K. S. \& Gordienko, L. P. Metabolic Changes in Salivary Glands of Rats under GlutamateInduced Obesity. J. Dent. Oral Disord. Ther., 2(3):1-4, 2014. 
Bunyan, J.; Murrell, E. A. \& Shah, P. P. The induction of obesity in rodents by means of monosodium glutamate. Br. J. Nutr., 35:25-39, 1976.

Choromanska, K.; Choromanska, B.; Dabrowska, E.; Baczek, W.; Mysliwiec, P.; Dadan, J. \& Zalewska, A. Saliva of obese patients - is it different? Postepy Hig. Med. Dosw. (Online), 69:1190-5, 2015.

Contini, M. C.; Millen, N.; Riera, L. \& Mahieu, S. Kidney and liver functions and stress oxidative markers of monosodium glutamateinduced obese rats. Food Public Health, 2:168-77, 2012.

Collison, K. S.; Maqbool, Z. M.; Inglis, A. L.; Makhoul, N. J.; Saleh, S. M.; Bakheet, R. H.; Al-Johi, M. A.; Al-Rabiah, R. K.; Zaidi, M. Z. \& Al-Mohanna, F. A. Effect of dietary monosodium glutamate on HFCSInduced Hepatic Steatosis: expression profiles in the liver and visceral fat. Obesity (Silver Spring), 18:1122-34, 2010a.

Collison, K. S.; Makhoul, N. J.; Inglis, A.; Al-Johi, M.; Zaidi, M. Z.; Maqbool, Z.; Saleh, S. M.; Bakheet, R.; Mondreal, R.; Al-Rabiah, R.; Shoukri, M.; Milgram, N. W. \& Al-Mohanna, F. A. Dietary transfat combined with monosodium glutamate induces dyslipidemia and impairs spatial memory. Physiol. Behav., 99:334-42, 2010.

De Campos, M. M.; Kobayashi, F. Y.; Barbosa, Tde, S.; Costa, S. DA. S.; Lucas, B. DE. L. \& Castelo, P. M. Characteristics of salivary secretion in normal-weight, overweight and obese children: a preliminary study salivary composition and excessive fat tissue. Odontology, 102:31824, 2014.

Dolnikoff, M.; Martin-Hidalgo, A.; Machado, U. F.; Lima, F. B. \& Herrera, E. Decreased lipolysis and enhanced glycerol and glucose utilization by adipose tissue prior to development of obesity in monosodium glutamate (MSG) treated-rats. Int. J. Obes. Relat. Metab. Disord., 25:426-33, 2001.

Ebert, A. G. Evidence that MSG des not induce obesity. Obesity, 17:62930, 2009.

Flink, H.; Bergdahl, M.; Tegelberg, A.; Rosenblad, A. \& Lagerlöf, F. Prevalence of hyposalivation in relation to general health, body mass index and remaining teeth in different age groups of adults. Community Dent. Oral Epidemiol., 36:523-31, 2008.

He, K.; Zhao, L.; Daviglus, M. L.; Dyer, A. R.; Van Horn, L.; Garside, D.; Zhu, L.; Guo, D.; Wu, Y.; Zhou, B.; Stamler, J. \& INTERMAP Cooperative Research Group. Cooperative Research Group. Association of monosodium glutamate intake with overweight in Chinese adults: the INTERMAP Study. Obesity (Silver Spring), 16:1875-80, 2008.

He, K.; Du, S.; Xun, P.; Sharma, S.; Wang, H.; Zhai, F. \& Popkin, B. Consumption of monosodium glutamate in relation to incidence of overweight in Chinese adults. China Health and Nutrition Survey (CHNS). Am. J. Clin. Nutr., 93:1328-36, 2011.

Herrera, J. L.; Lyons, M. F. 2nd. \& Johnson, L. F. Saliva: Its role in health and disease. J. Clin. Gastroenterol., 10:569-78, 1988.

Hirata, A. E.; Andrade, I. S.; Vaskevicius, P. \& Dolnikoff, M. S. Monosodium glutamate (MSG)-obese rats develop glucose intolerance and insulin resistance to peripheral glucose uptake. Braz. J. Medical. Biol. Res., 30:671-4, 1997.

Hordiienko, L. P.; Berehova, T. V.; Neporada, K. S. \& Falalieieva, T. M. Oxidative stress development in the tissues of salivary glands of rats in conditions of monosodium glutamate-induced obesity. Fiziol. Zh., 60(4):105-7, 2014.

Humphrey, S. P. \& Williamson, R. T. A review of saliva: Normal composition, flow, and function. J. Prosthet. Dent., 85:162-9, 2001.

Husarova, V. \& Ostatnikova, D. Monosodium glutamate toxic effects and their implications for human intake: a review. JMED Research, 2013.

Ibuki, F. K.; Simoes, A. \& Nogueira, F. N. Antioxidant enzymatic defense in salivary glands of streptozotocin-induced diabetic rats: a temporal study. Cell Biochem. Func., 28:503-8, 2010.

Inoue, S.; Campfield, L. A. \& Bray, G. A. Comparison of metabolic alterations in hypothalamic and high fat diet-induced obesity. Am. J. Physiol., 233:R162-8, 1977.
Insawang, T.; Selmi, C.; Chaon, U.; Pethlert, S.; Yongvanit, P.; Areejitranusorn, P.; Boonsiri, P.; Khampitak, T.; Tangrassameeprasert, R.; Pinitsoontorn, C.; Prasongwattana, V.; Gershwin, M. E. \& Hammock, B. D. Monosodium glutamate (MSG) intake is associated with the prevalence of metabolic syndrome in a rural Thai population. Nutr. Metab. (Lond)., 9:50, 2012.

Iwase, M.; Ichikawa, K.; Tashiro, K.; Iino, K.; Shinohara, N.; Ibayashi, S.; Yoshinari, M. \& Fujishima, M. Effects of monosodium glutamateinduced obesity in spontaneously hypertensive rats vs. Wistar Kyoto rats: serum leptin and blood flow to brown adipose tissue. Hypertens. Res., 23:503-10, 2000.

Jinap, S. \& Hajeb, P. Glutamate. Its applications in food and contribution to health. Appetite, 55:1-10, 2010.

Kondoh, T. \& Torii, K. MSG suppresses weight gain, fat deposition, and plasma leptin levels in male Sprague-Dawley rats. Physiol. Behav., 95:135-44, 1995

Leone, C. W. \& Oppenheim, F. G. Physical and chemical aspects of saliva as indicators of risk for dental caries in humans. J. Dent. Educ., 65:1054-62, 2001.

Lilliu, M. A.; Solinas, P. \& Cossu, M. Diabetes causes morphological changes in human submandibular gland: a morphometric study. $J$. Oral Pathol Med., 44:291-5, 2015.

López-Miranda, V.; Soto-Montenegro, M. L.; Uranga-Ocio, J. A.; Vera, G.; Herradón, E.; González, C.; Blas, C.; Martínez-Villaluenga, M.; López-Pérez, A. E.; Desco, M. \& Abalo, R. Effects of chronic dietary exposure to monosodium glutamate on feeding behavior, adiposity, gastrointestinal motility, and cardiovascular function in healthy adult rats. Neurogastroenterol. Motil., 27:1559-70, 2015.

Lynge Pedersen, A. M. \& Belstrøm, D. The role of natural salivary defences in maintaining a healthy oral microbiota. J. Dent., 80:S3S12, 2019.

Mandarim-de-Lacerda, C. A. \& del Sol, M. Tips for studies with quantitative morphology (morphometry and stereology). Int. J. Morphol., 35:1482-94, 2017.

Marmo, M. R.; Dolnikoff, M. S.; Kettelhut, I. C.; Matsushita, D. M.; Hell, N. S. \& Lima, F. B. Neonatal monosodium glutamate treatment increases epididymal adipose tissue sensitivity to insulin in threemonth old rats. Braz. J. Med. Biol. Res., 27:1249-53, 1994.

Matczuk, J.; Zalewska, A.; ukaszuk, B.; Knas, M.; Maciejczyk, M.; Garbowska, M.; Ziembicka, D. M.; Waszkiel, D.; Chabowski, A.; $\mathrm{Z}$ endzian-Piotrowska, M. \& Kurek, K. Insulin resistance and obesity affect lipid profile in the salivary glands. J. Diabetes Res., 2016; Article ID 8163474.

Mathus-Vliegen, E. M. \& Nikkel, D. \& Brand, H. S. Oral aspects of obesity. Int. Dent. J., 57:249-56, 2007.

Matysková, R.; Maletínská, L.; Maixnerová, J.; Pirník, Z.; Kiss, A. \& Zelezná, B. Comparison of the obesity phenotypes related to monosodium glutamate effect on arcuate nucleus and/or the high fat diet feeding in C57B1/6 and NMR1 mice. Physiol. Res., 57:727-34, 2008.

Miranda, R. A.; Da Silva Franco, C. C.; De Oliveira, J. C.; Barella, L. F.; Tófolo, L. P.; Ribeiro, T. A.; Pavanello, A.; Da Conceição, E. P.; Torrezan, R.; Armitage, J.; Lisboa, P. C.; De Moura, E. G.; De Freitas Mathias, P. C. \& Vieira, E. Cross-fostering reduces obesity induced by early exposure to monosodium glutamate in male rats. Endocrine, 55:101-12, 2017.

Modéer, T.; Blomberg, C. C.; Wondimu, B.; Julihn, A. \& Marcus, C. Association between obesity, flow rate of whole saliva, and dental caries in adolescents. Obesity, 18:2367-73, 2010.

Modéer, T.; Blomberg, C.; Wondimu, B.; Lindberg, T. Y. \& Marcus, C. Association between obesity and periodontal risk indicators in adolescents. Int. J. Pediatr. Obes., 6:e264-70, 2011.

Mozaffari, M. S.; Abdelsayed, R.; Zakhary, I.; El-Salanty, M.; Liu, J. Y.; Wimborne, H. \& El-Marakby, A. Submandibular gland and caries susceptibility in the obese Zucker rat. J. Oral Pathol. Med., 40:194200, 2011. 
Pannunzio, E.; Amancio, O. M.; Vitalle, M. S.; Souza, D. N.; Mendes, F. M. \& Nicolau, J. Analysis of the stimulated whole saliva in overweight and obese school children. Rev. Assoc. Med. Bras., 56:32-6, 2010.

Pedersen, A.; Sørensen, C. E.; Proctor, G. B. \& Carpenter, G. H. Salivary functions in mastication, taste and textural perception, swallowing and initial digestion. Oral Dis., 24:1399-416, 2018.

Renzi, A.; Utrilla, S. L.; Camarqo, L. A. A.; Saad, W. A.; Luca Júnior, L. A.; Menani, J. V. \& Roslindo, N. C. Morphological alterations on the rat submandibular gland caused by lesion of the ventromedial nucleus of the hypothalamus. Rev. Odont. UNESP, 18:157-64, 1989.

Rodrigues, L.; Mouta, R.; Costa, A. R.; Pereira, A.; Capela, E.; Silva, F.; Amado, F.; Antunes, C. M. \& Lamy, E. Effects of high fat diet on salivary a-amylase, serum parameters and food consumption in rats. Arch. Oral Biol., 60:854-62. 2015.

Rohleder, N. \& Nater, U. M. Determinants of salivary alpha-amylase in humans and methodological considerations. Psychoneuroendocrinology, 34:469-85, 2009.

Saito, T.; Shimazaki, Y.; Kiyohara, Y.; Kato, I.; Kubo, M.; Iida, M. \& Yamashita, Y. Relationship between obesity, glucose tolerance, and periodontal disease in Japanese women: the Hisayama study. $J$. Periodontal Res., 40:346-53, 2005.

Salamonowicz, M. M.; Zalewska, A. \& Maciejczyk, M. Oral consequences of obesity and metabolic syndrome in children and adolescents. Dent. Med. Probl., 56:97-104, 2019.

Sassaki, K. T.; Delbem, A. C.; Dos Santos, O. A.; Shimabucoro, C. E.; Nakamune, A. C.; Bedran-De-Castro, J. C. \& Oliveira-Filho, R. M Neuroendocrine alterations impair enamel mineralization, tooth eruption and saliva in rats. Pesqui. Odontol. Bras., 17:5-10, 2003.

Scherle W. A simple method for volumetry of organs in quantitative stereology. Mikroskopie, 26:57-63, 1970.

Shi, Z.; Luscombe-Marsh, N. D.; Wittert, G. A.; Yuan, B.; Dai, Y.; Pan, X. \& Taylor, A. W. Monosodium glutamate is not associated with obesity or a greater prevalence of weight gain over 5 years: findings from the Jiangsu Nutrition Study of Chinese adults. Br. J. Nutr., 104:457-63, 2010.

Takai, N.; Uchihashi, K.; Yoshida, Y. \& Kakudo, Y. Salivational and histological damage of submandibular and sublingual glands in Streptozotocin-induced diabetic rats. J. Osaka Dent. Univ., 17:6572, 1983.

Ueda, H.; Yagi, T.; Amitani, H.; Asakawa, A.; Ikeda, S. \& Miyawaki, S. The roles of salivary secretion, brain-gut peptides, and oral hygiene in obesity. Obes. Res. Clin. Pract., 7:e321-e329. 2013.

von Diemen, V.; Trindade, N. E. \& Trindade, M. R. Experimental model to induce obesity in rats. Acta Cir. Bras., 21:425-9, 2006.

Zalewska, A.; Knás, M.; Gindzienska-Sieskiewicz, E.; Waszkiewicz, N.; Klimiuk, A.; Litwin, K.; Sierakowski, S. \& Waszkiel, D. Salivary antioxidants in patients with systemic sclerosis. J. Oral Pathol. Med., 43:61-8, 2014.

\author{
Corresponding author: \\ Ignacio Roa Henríquez \\ Unidad de Morfología \\ Departamento de Ciencias Básicas Biomédicas \\ Facultad de Ciencias de la Salud \\ Universidad de Talca \\ Lircay Av. s / n, Talca \\ CHILE
}

E-mail: iroa@utalca.cl

Recibido : 28-02-2020

Aceptado: 23-03-2020 